研 究速 報

\title{
ニューラルネットの構造決定における 遺伝的アルゴリズムの応用*
}

田中 雅博 $^{* *} \cdot$ 古賀 久司 ${ }^{* * *} \cdot$ 谷野 哲三**

\section{An Application of the Genetic Algorithm to the Structure \\ Determination of a Neural Network*}

Masahiro TANAKA ${ }^{* *}$, Hisashi KogA ${ }^{* * *}$ and Tetsuzo TAnIno**

\section{1.はじめに}

階層型ニューラルネットワークはその学習方法が問題 に依存しないてとから, パターン認識などに盛んに応用 されている.また，隠れ層を 1 層持つネットワークは， その隠れ層のユニット数を制限しなければ任意の連続写 像を任意の精度で近似できることがわかっている11. しかし，ある問題が与えられたとき，隠れ層にいくつの ユニットが必要なのかを直接知る方法はまだ見つけられ ていないため, 適当に設定して試行錯誤を行う方法がと られるのが普通である. 与えられた問題に対して階層型 フィードフォワード・ニューラルネットワークをパターン 認識のモデル, あるいは連続值出力をもつ非線形関数器 として用いようとするとき, 二つの異なったレベルの学 習, 決定問題を解決する必要がある. まず, 上位（基礎 的）レベルの問題として, ユニット数や接続の有無を決 定する構造決定問題がある. 次に下位レベルの問題とし てユニット間の重み係数の学習という問題がある.

ての問題の中で構造だけを決めようとしても結局重み 係数を求めてネットワークの性能を調べてみないと決め ることはできない.

階層型ニューラルネットの学習方法としては, 処理を 高速にするために 1 次元探索を用いず, 最急降下法にお いて学習係数を固定して適用するバックプロパゲーショ ン $(\mathrm{BP})$ 法が広く用いられている. しかし, 学習係数が 大きすぎると, 初期段階で発散したり学習するたびに最

* 原稿受付 1994 年 5 月 24 日

** 岡山大学 工学部 Faculty of Engineering, Okayama University ; Tsushimanaka 3-chome 1-1, Okayama city, Okayama 700, JAPAN

*** 岡山大学 大学院 工学研究科 Graduate School of Engineering, Okayama University; ditto

Key Words : neural network, genetic algorithm, structure determination, back propagation, speech recognition.
適点を飛び越えて振動するような状況が起こる可能性が ある. 一方, 学習係数が小さすぎると, なかなか収束せ ず局所解にあ陥りやすい，乙のような問題があるため, モーメンタムを持った学習式や学習係数を適応的に決め る方法 ${ }^{2}$ が提案されている. 後者の方法では, 現在得ら れている学習係数で 1 ステップ学習してネットワークの 性能が改善されれば, 次の段階では学習係数を $\alpha$ 倍 ( $\alpha>1)$ して学習係数を大きくし，そうでなければ学習 係数を $\beta$ 倍 $(\beta<1)$ して学習係数を小さくする. ての 方法では，いったん壁に突き当たるとほとんど 0 にまで 学習係数を小さくしなければ次に進めない，また隠れ層 ユニットの数によってあ適した学習係数の変化は異なる ことが予想される. てのように既存の方法は, それぞれ一 長一短があり，決定的に優れた方法は見つかっていない.

本速報では, 実数值をコードに持つ遺伝的アルゴリズ ム (GA) を用いて構造と学習係数を決定する方法を考 案し, 実際に音声認識問題に適用して良い結果を得たの で報告する。

\section{2. ネットワーク}

こてで用いる階層型ニューラルネットは入力層, 隠れ 層 1 層, 出力層よりなる 3 層構造とする. 入力層は入力 值 $u_{i}$ をそのまま伝達するあのとし, 隠れ層はユニット $j$ 亿入力するシナプスを伝わってくる一つ手前の層, す なわち入力層のユニットからの出力值にシナプスの重み $w_{i j}$ を掛けた值を足し合わせた值 $s_{j}=\sum_{i} w_{i j} u_{i}$ をシグ モイド関数で変換した值を出力する.

\section{3. 学習上の問題点と GA のための 個体コード}

階層型ニューラルネットワークの学習で使われるバッ クプロパゲーションでは, 重み係数よりなるベクトル 
$W$ が

$$
W(k)=W(k-1)-c \nabla_{W} E(x, y, \hat{y}(W(k-1)))
$$

により修正される。乙こに $x$ は入力信号, $E(x, y$, $\hat{y}(W(k-1)))$ は教師出力信号 $y$ とネットワーク $W(k-1)$ による推定值との誤差関数であり, $\nabla_{W} E$ は $E$ の $W$ にるる勾配を表わす。 $E$ の関数形を定めれば $\nabla_{W} E(x, y, \hat{y}(W(k-1)))$ の具体的な式は容易に導け るのでここではその記述を省略する.

実際に計算を実行してみると，学習の初期段階では誤 差が大きいため学習係数が小さくても学習は比較的速く 進むが，ある程度学習が進んだ後は誤差が小さいためゲ インである学習係数は大きめにする必要があることがわ かる. そこで，乙てでは，学習を 3 段階に分け，それぞ れの段階で固定係数を用いることにし，最も適した前中 後期の境界の時刻屯学習することにする.

GA の個体としては, 中間層のユニット数 $(m)$, 前期, 中期, 後期の学習係数 (各 $c_{1}, c_{2}, c_{3}$ ), 前期, 中期の学 習回数 $n_{1}, n_{2}$ としてコード化する. ただし， $m$ が整数 值であるほかは実数とする，乙のような個体を持つ GA を実数值 GA と呼ぶ3 が，乙のような形の GA は，本速 報で扱う問題のように本来 2 進数に関係のない問題では, さまざまな観点で通常の 2 進数に基づいたものよりも優 れている，すなわち，コードが短く，突然変異や交叉が コードに起因して本来の問題における決定変数の定義域 の中にカバーできない領域が生じることが少なく, 実行 可能領域の形に適応が容易なオペレーションが可能な のである. 実数值を用いた進化的アルゴリズムには，ほ かに進化的プログラミング (Evolutionary Programming : EP), 進化戦略 (Evolution Strategy : ES) あある ${ }^{4)} \mathrm{EP}$ は組み替え演算を用いず突然変異と命名 された個体単体での摂動を行うものである. ES は組み 換え演算を持ち, 実数值 GA と類似しているが, 基本 的には集団中の個体単位での進化を主眼に扔いており, 本速報ではそれらを用いず実数值 GA を用いた。 それ は, この問題が, その個体を構成する要素がある程度普 遍的な最適值を持つ一方，それらの要素を組み合わせる ことによりエピスタシスをあつという最適化問題でああ るため, GA でいう積木仮説 ${ }^{5), 6)}$ の働くことが期待され るからである.

\section{4. アルゴリズム}

交叉は 2 進数表現の GA の交叉と同様の交叉と単純 算術交叉, 単一算術交叉, 全体算術交叉の三つの算術交 叉を用い, 突然変異は一様突然变異, 非一様突然変異, 境界突然変異という突然変異を行う ${ }^{2}$.
これらを含めた全体のアルゴリズムは次のとおりであ る.

1）初期集団の生成

2）集団中の個体それぞれについて BP で学習し評価 值を与える.

3）与えられた評価值の大きさに比例して GA の複製 (reproduction) 操作を行う.

4）新しく生成された集団中の個体について BP で学 習を行い評価值を与える.

5）3）４）を有限回繰り返し，最終的に得られた個体 集団中でもっと屯評価值の良い個体を最適な構造 を表わす個体とみなす。

\section{5. 音声認識への応用}

ここでは日本語母音の音声実データを認識するために 個体数 25 で実験を行った，学習データとして 3 人の発 声者による 100 組のデータを用いた. また BP の学習回 数は 900 回に固定した. $E_{k}$ を, 総学習回数の $k \%$ 学習 を終えたときの教師信号に対する判定結果の䛊差 2 乗平 均とする.

この実験では，まず 3 層のニューラルネットワークの 学習が終了した時の䛊差 $\left(E_{99}+E_{100}\right) / 2$ (実際にはパラ メータの值によって誤差の変動が大きいため本值を用い た.), 総学習回数の 8 割を終えたときの誤差 $E_{80}$, 学習 終了時の正解率 $R$ を用いて評価値を与えた。 すなおち, 個体 $i$ に対し

$$
E V(i)=\frac{1}{E_{80}(i)}+\frac{2}{E_{99}(i)+E_{100}(i)}+10 R(i)
$$

とした

誤差の収束の過程はFig. 1 亿示す。異なるデー夕を 用いた 5 回の実験では，いずれも学習係数が，それぞれ 前期 $c_{1}=0.07 \pm 0.01$, 中期 $c_{2}=0.17 \pm 0.04$, 後期 $c_{3}=$

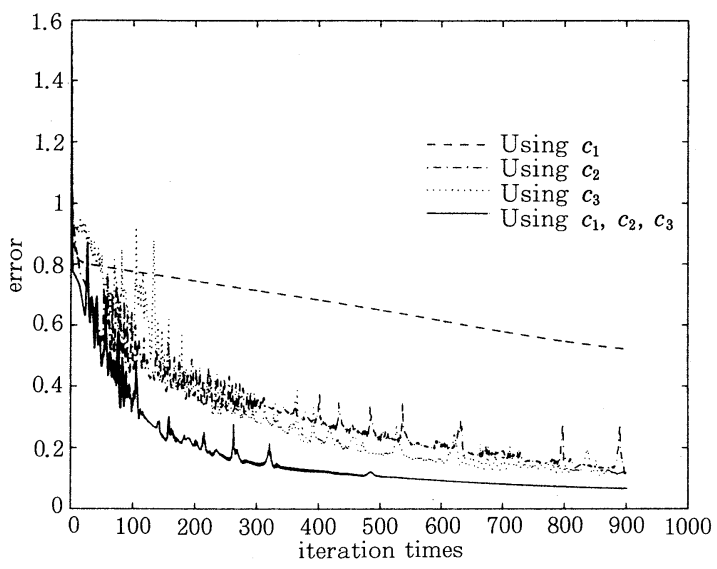

Fig. 1 Square error of the estimates 
$0.39 \pm 0.15$, ユニット数は 9 または 10 となり，前期学習 回数は 15 前後, 中期の学習回数は 100 前後のほぼ等し

い構造をもつ個体が得られた。

\section{6. おわりに}

上記手法でプログラムを作成し複数回実行したが，ほ ぼ同じような結果が得られたととから，乙の問題に対し て最適に近い形のコードが得られたものと考えられる. この結果より, 本速報で提案する手法の有効性が示せた.

\section{参 考 文 献}

1) 舩橋 : 階層型ニューラルネットワークの原理的機能 ; 計測 之制御, Vol. 30, No. 4, pp. 280 284 (1991)

2) T. P. Vogl, J. K. Mangis, A. K. Rigler, W. T. Zink and D. H. Alkon : Accelerating the Convergence of the Backpropagation Method; Biological Cybernetics, Vol. 59, No. 4, pp. 257 263 (1988)

3) Z. Michalewicz : Genetic Algolithms + Data Structures = Evolution Programs, Springer-Verlag (1992)

4) T. Bäck and H.-P. Schwefel : An Overview of Evolutionary Algorithms for Parameter Optimization ; Eyolutionary Computation, Vol. 1, No. 1, pp. 1 23 (1993)

5) J.H. Holland: Adaptation in Natural and Artificial Systems, MIT Press (1992)

6) D. E. Goldberg : Genetic Algorithm in Search, Optimization, and Machine Learning, Addison Wesley (1989) 